\title{
Head Teacher AS A Leader: An Analysis of Head Teachers Practices Based on Hersey Blanchard Model in Azad Jammu \& Kashmir
}

\author{
Khalid Mahmood \\ PhD Education, Mohi ud din Islamic University Narian Sharif Azad Jammu \\ \&Kashmir. \\ Email: khalid552233@gmail.com
}

Muhammad Rifaqat

PhD Education, Mohi ud din Islamic University Narian Sharif Azad Jammu \& Kashmir. Email: muhammadrifaqat9@gmail.com

\author{
Sufi Amin \\ Research Fellow, Department of Education, International Islamic University \\ Islamabad.
}

Received on: 08-10-2021

Accepted on: 09-11-2021

\section{Abstract}

The purpose of the study was to compare the leadership practices based on Hersey Blanchard model in AJK. The major objective of this study were to: compare the leadership practices of male and female Head teacher based on Hersey Blanchard Model, compare the leadership practices of public and private school Head teachers based on Hersey Blanchard Model. The study was descriptive in nature as it based on survey. The population of the study were Head Teachers of three District of AJK i.e. (kotli, Sudhnuti and Poonch) Stratified sampling technique was used for selecting the sample. The sample is selected according to (Gay, 2009). Data were collected using a survey questionnaire prepared on five-point Likert scale. Collected data were analyzed through independent sample t- test. On the basis of analysis and findings conclusion were drawn that the leadership practices of male Head teachers are better as compare to female Head teachers regarding direction and coaching while in supporting and delegation female Head teachers' practices are better as compare to male Head teachers' practices. It was concluded that the leadership practices of private Head teachers are better as compare to public Head teachers regarding direction, coaching and supporting while in delegation, public Head teachers' practices are better than private Head teachers' practices. The finding of the study recommended some ideas to be made for improving leadership practices. Government should provide forum in which both public and Private Head teacher 
Vol. II, Issue 3, Oct - December 2021

ISSN No: (ONLINE): 2710-043

www.irjei.com
International Research Journal of Education and Innovation

ISSN No: ISSN (PRINT): 2710-0448

DOI: https://doi.org/10.53575/irjei.v2.03(21)3.35-43

Head Teacher AS A Leader: An Analysis of Head Teachers Practices Based ...

share their practices. Government should upgrade their teacher and Head teacher regarding coaching according to modern era. Department of education should organize a proper ongoing training for their teacher and Head teacher regarding directing, coaching, supporting and delegation. The management of private schools should organize a proper ongoing training for their teacher and Head teacher regarding directing, coaching, supporting and delegation.

Keywords: Leader, Public, Private, Comparison, Hersey Blanchard, Model

\section{Introduction}

Leadership is an advance way of working with people in an institution to achieve the task. Leadership helps in turning plans and decisions into action. There is different leadership styles are being used in the world. Leadership is a major problem in the world and especially in Pakistan and Azad Jammu and Kashmir (Awan, 2014). In education, leadership entails directing the actions of those involved in mind training toward the fulfilment of organizational goals established by those who have organized themselves for it. The interaction between individuals who desire to lead and those who choose to follow is known as leadership (Kouzes \& Posner, 2002). The school heads/principals execute this leadership in the educational system. A leader's style has been defined as the appealing manner in which he or she exerts control over his or her followers (Yukl, 2002). The ability to influence is most likely inherited from a developmental stage during which the kid learns the details of control, authority, supremacy, and respect. Someone who can mix the ability to think about and the capability to influence would be the best leader/principal (Kets, 2006). By developing commitment to the best of organization/schools objective, teaching and learning and empowering teachers to accomplish those objectives. (Luneburge, 2007). There are different kinds of leadership theories such as Trait theories, Behavioral theories, Contingency theories, Transactional theories, Transformational theories, Great Man theories, Hersey and Blanchard situational theories and Management theories.

One of the best leadership theory which researcher will apply in his research is Hersey Blanchard Situational Leadership Theory. In this theory Hersey Blanchard had explained the four types of subordinates and according to situation four types of leadership style to handle them (Mulder, 2012).

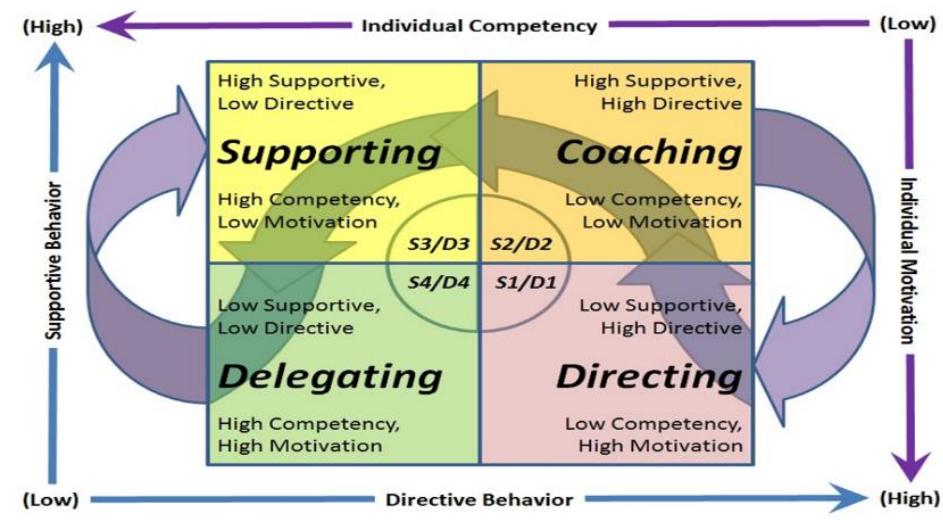

Fig: Situational leadership Model by Ken Blanchard (2008) 
Vol. II, Issue 3, Oct - December 2021

ISSN No: (ONLINE): 2710-043

www.irjei.com
International Research Journal of Education and Innovation

ISSN No: ISSN (PRINT): 2710-0448

DOI: https://doi.org/10.53575/irjei.v2.03(21)3.35-43

Head Teacher AS A Leader: An Analysis of Head Teachers Practices Based ...

This model provides a quick guidance to help leaders access the followers' level of commitment and competency then matching leadership styles. D stands for development level of follower (high/low), while S refers to leadership style (directing, coaching, supporting and delegating) there is no such study has been done on situational leadership theory in AJ\&K. Hence, Researcher has realised this deficiency and aim to do work on it .This study is innovative in a sense that it will analyse the leadership practices based on Hersey blanchard situational Model.

\section{Statement of the Problem}

Leadership helps in turning plans and decisions into action. There are different leadership practices being used in the world. There is no uniformity in leadership practices. No study was conducted in leadership practices based on HB model in AJ\&K. Researcher realized this gap so, current study will be comparison of leadership practices of public and private secondary school Head teachers in AJ\&K.

\section{Objective of the Study}

The objectives of the study were;

1. To find out the leadership practices of Public Head teachers based on Hersey Blanchard Model

2. To explore the leadership practices of Private Head teachers based on Hersey Blanchard Model

3. To compare the leadership practices of male and female Head teachers based on Hersey Blanchard Model.

\section{Research Questions}

1. What are leadership practices of male Head teacher based on Hersey Blanchard Model?

2. What are leadership practices of female Head teachers based on Hersey Blanchard Model?

3. What are leadership practices of Head teachers in public schools based on Hersey Blanchard Model?

4. What are leadership practices of Head teachers in private schools based on Hersey Blanchard Model?

\section{Significance of the Study}

This study is innovative in this sense because it was most important study of Hersey Blanchard situational leadership model in AJ\&K. This study is provided information for teachers how they deal their students according to their maturity level. It gives direction to policy makers in future. Lastly, it provided, at least, a basis for further studies related to leadership practices of the AJ\&K school teachers.

\section{Delimitation}

The study delimited to:

1. Public and Private secondary schools

2. Three districts (Kotli, Sudhnuti and Poonch) of AJ\&K.

\section{Methodology}

The study was descriptive in nature as it based on survey. Data was collected using a survey 
Vol. II, Issue 3, Oct - December 2021

ISSN No: (ONLINE): 2710-043

www.irjei.com
International Research Journal of Education and Innovation

ISSN No: ISSN (PRINT): 2710-0448

DOI: https://doi.org/10.53575/irjei.v2.03(21)3.35-43

Head Teacher AS A Leader: An Analysis of Head Teachers Practices Based ...

questionnaire prepared at five-point Likert scale. The population of study was included all secondary school Head teacher's male and female of public and private schools in three districts of AJ\&K. Stratified sampling technique was used for selecting the sample. The sample is selected according to (Gay, 2009). The population of research was included all secondary institute principal/head teacher male and female of government and private institutes in three districts of AJ\&K. There are total 468 male and 565 female secondary school head teachers are working in AJ\&K. Stratified sampling technique is used for selecting the sample. The sample was selected according to Gay, (2009). There are two hundred seventeen (217) male Head teachers and Two hundred thirty (230) female Head teachers are selected by using Stratified sampling technique. This study was carried out using a survey questionnaire at fivepoint Likert scale. In this study one questionnaire was constructed for male and female head teachers. Data were collected using a survey questionnaire prepared on five-point Likert scale. Collected data were analyzed through independent sample t- test.

\section{Results}

Table 1 Mean and Standard Deviation of Principal Opinions regarding Direction

\begin{tabular}{llll}
\hline S.No & Statements (Direction) & M & SD \\
\hline 1 & I give directions to the teacher in one to one meeting. & 3.47 & .50 \\
2 & I give directions to the teachers in groups for effective teaching. & 3.92 & .70 \\
3 & I try to explore the areas where the teachers are lagging behind. & 3.69 & .86 \\
4 & I examine the teachers during teaching. & 3.04 & 1.05 \\
5 & I nominate the teachers to participate in ongoing trainings. & 3.78 & .91 \\
6 & I create opportunities for teachers to work with experienced teacher. & 3.12 & .81 \\
7 & I avoid put extra burden on teachers. & 3.87 & .73 \\
8 & I regularly observe the teachers during completion of assigned work. & 3.44 & 1.02 \\
9 & I guide the teachers to improve the lesson planning skills. & 3.74 & .43 \\
10 & I need training for multi directional leadership style. & 4.19 & .39
\end{tabular}

Table 1 reveals that, all respondents were agreed on the statements and having highest $\mathrm{M}=4.19$ that I need training for multi directional leadership style. While other statements also highest mean scores like, I give directions to the teachers in groups for effective teaching, I give directions to the teachers in groups for effective teaching, I guide the teachers to improve the lesson planning skills, I avoid put extra burden on teachers, I nominate the teachers to participate in ongoing trainings, I try to explore the areas where the teachers are lagging behind, and I regularly observe the teachers during completion of assigned work. And two statements like, I examine the teachers during teaching, and I create opportunities for teachers to work with experienced teacher reveals neutral responses on statements. It was concluded that most of the responses of the respondents had positive attitudes regarding direction.

Table 2 Mean and Standard Deviation of Principal Opinions regarding Coaching

\begin{tabular}{llll}
\hline S.No & Statements (Coaching) & M & SD \\
\hline 1 & I coach the teachers for assessment in one to one meeting. & 3.28 & .45 \\
2 & I motivate the teachers in groups for effective assessment. & 3.87 & .32 \\
3 & I lead the teachers during specified tasks. & 4.08 & .58 \\
4 & I facilitate the teachers to participate in ongoing training. & 3.82 & .91
\end{tabular}


Vol. II, Issue 3, Oct - December 2021

ISSN No: (ONLINE): 2710-043

www.irjei.com
International Research Journal of Education and Innovation

ISSN No: ISSN (PRINT): 2710-0448

DOI: https://doi.org/10.53575/irjei.v2.03(21)3.35-43

Head Teacher AS A Leader: An Analysis of Head Teachers Practices Based ...

\begin{tabular}{llll}
\hline \hline 5 & I observe the teachers during specified tasks. & 3.73 & 1.12 \\
6 & I encourage the teacher to work with experienced teachers. & 3.57 & .79 \\
7 & I appreciate the teachers on the completion of the assigned task. & 4.14 & .87 \\
8 & I evaluate the teacher's performance regularly. & 3.40 & 1.21 \\
9 & I am aware of different result reporting techniques. & 3.47 & .70 \\
10 & I need training to refresh my knowledge and skills. & 3.51 & .82 \\
& & & \\
\hline
\end{tabular}

Table 2 shows that, all respondents were agreed on the statements and having highest $\mathrm{M}=4.14$ that $\mathrm{I}$ appreciate the teachers on the completion of the assigned task. While other statements also highest mean scores like, I motivate the teachers in groups for effective assessment, I lead the teachers during specified tasks, I facilitate the teachers to participate in ongoing training, I encourage the teacher to work with experienced teachers, I am aware of different result reporting techniques, I need training to refresh my knowledge and skills, I evaluate the teacher's performance regularly, and I observe the teachers during specified tasks. And one statement like, I coach the teachers for assessment in one to one meeting presented neutral responses on statements. It was concluded that most of the responses of the respondents had positive attitudes regarding coaching.

Table 3 Mean and Standard Deviation of Principal Opinions regarding Supporting

\begin{tabular}{llll}
\hline S.No & Statements (Supporting) & M & SD \\
\hline 1 & I support the teachers in co-curricular activities. & 4.02 & .63 \\
2 & I support the teachers in classroom activities. & 3.88 & .46 \\
3 & I provide motivational literature to the teachers. & 3.50 & .80 \\
4 & I provide motivational videos to the teachers. & 3.08 & 1.25 \\
5 & I give award to the teachers after completion of task. & 3.56 & .94 \\
6 & I produce sense of competition among teachers. & 3.60 & .78 \\
7 & The teachers are accountable on showing low results. & 3.73 & .83 \\
8 & Positive attitude towards the use of co-curricular activities. & 4.04 & .59 \\
9 & I have a command on the counselling skill. & 3.21 & .74 \\
10 & Need of training for multi dimension supportive techniques. & 3.98 & .17
\end{tabular}

Table 3 presents that, all respondents were agreed on the statements and having highest $\mathrm{M}=4.04$ that Positive attitude towards the use of co-curricular activities. While other statements also positives mean scores like, I support the teachers in co-curricular activities, I support the teachers in classroom activities, I provide motivational literature to the teachers, I give award to the teachers after completion of task, I produce sense of competition among teachers, The teachers are accountable on showing low results, and Need of training for multi dimension supportive techniques. And two statements like, I provide motivational videos to the teachers, and I have a command on the counselling skill. It was concluded that most of the responses of the respondents had positive attitudes regarding supporting.

Table 4 Mean and Standard Deviation of Principal Opinions regarding Delegation

\begin{tabular}{llll}
\hline S.No & Statements (Delegating) & M & SD \\
\hline 1 & I delegate research work to the teachers. & 2.93 & .99 \\
2 & I monitor the given task. & 4.00 & .61 \\
3 & I avoid interruption during work. & 3.92 & .67
\end{tabular}


Vol. II, Issue 3, Oct - December 2021

ISSN No: (ONLINE): 2710-043

www.irjei.com
International Research Journal of Education and Innovation

ISSN No: ISSN (PRINT): 2710-0448

DOI: https://doi.org/10.53575/irjei.v2.03(21)3.35-43

Head Teacher AS A Leader: An Analysis of Head Teachers Practices Based ...

\begin{tabular}{llll}
\hline \hline 4 & I always appreciate the teachers. & 3.59 & .49 \\
5 & I build the confidence of teachers. & 3.79 & .40 \\
6 & I provide complete freedom in teaching learning activities. & 3.58 & .49 \\
7 & I provide feedback at the end of task. & 2.98 & .64 \\
8 & I provide competitive atmosphere in school. & 3.65 & .78 \\
9 & Evaluate the effectiveness of different teaching methods. & 3.54 & .49 \\
10 & I need training regarding delegation of tasks to the teachers. & 4.02 & .63 \\
\end{tabular}

Table 4 presents that, all respondents were agreed on the statements and having highest $\mathrm{M}=4.02$ that I need training regarding delegation of tasks to the teachers. While other statements also positives mean scores like, I monitor the given task, I avoid interruption during work, I always appreciate the teachers, I build the confidence of teachers, I provide complete freedom in teaching learning activities, I provide competitive atmosphere in school, and Evaluate the effectiveness of different teaching methods. And two statements like, I delegate research work to the teachers, and I provide feedback at the end of task. It was concluded that most of the responses of the respondents had positive attitudes regarding delegating.

Table 5 Independent Sample T-Test Comparing Leadership Practice Regarding Direction of Male and Female Principals

\begin{tabular}{llllllll}
\hline S.No & Dependent variable & Gender & N & M & SD & T & Sig. \\
\hline 1 & Direction & Male & 132 & 32.17 & .86 & .62 & .19 \\
& & Female & 120 & 32.11 & & & \\
\hline
\end{tabular}

According to table 5, independent sample t-test table reveals that there is significant difference in the opinion of male and female regarding leadership practice direction score $\left(\mathrm{t}=.62\right.$, sig=.19, Mean $_{\text {male }}=32.17$, Mean female $\left.=32.11\right)$. Male principal rated leadership practice direction better than female principle.

Table 6 Independent Sample T-Test Comparing Leadership Practice Regarding Coaching of Male and Female Principals

\begin{tabular}{llllllll}
\hline S.No & Dependent variable & Gender & N & M & SD & T & Sig. \\
\hline 1 & Coaching & Male & 132 & 33.19 & .95 & .16 & .93 \\
& & Female & 120 & 33.21 & & & \\
\hline
\end{tabular}

According to table 6, independent sample t-test table reveals that there is no significant difference in the opinion of male and female regarding leadership practice coaching score $(\mathrm{t}=.16$, sig=.93, Mean male $=23.19$, Mean female $=33.21)$. Female principal rated leadership practice coaching better than male principal.

Table 7 Independent Sample T-Test Comparing Leadership Practice Regarding Supporting of Male and Female Principals

\begin{tabular}{llllllll}
\hline S.No & Dependent variable & Gender & N & M & SD & t & Sig. \\
\hline 1 & Supporting & Male & 132 & 31.46 & 1.22 & .93 & .90 \\
& & Female & 120 & 31.20 & & & \\
\hline
\end{tabular}

According to table 7, independent sample t-test table (Table 4.23) reveals that there is significant difference in the opinion of male and female regarding leadership practice 
Vol. II, Issue 3, Oct - December 2021

ISSN No: (ONLINE): 2710-043

www.irjei.com
International Research Journal of Education and Innovation

ISSN No: ISSN (PRINT): 2710-0448

DOI: https://doi.org/10.53575/irjei.v2.03(21)3.35-43

Head Teacher AS A Leader: An Analysis of Head Teachers Practices Based ...

supporting score $(\mathrm{t}=.93$, sig=.90, Mean male $=31.46$, Mean female $=31.20)$. Male principal rated leadership practice supporting better than female principal.

Table 8 Independent Sample T-Test Comparing Leadership Practice Regarding Delegation of Male and Female Principals

\begin{tabular}{llllllll}
\hline S.No & Dependent variable & Gender & N & M & SD & t & Sig. \\
\hline 1 & Delegation & Male & 132 & 35.47 & 2.96 & .35 & .93 \\
& & Female & 120 & 35.60 & & & \\
\hline
\end{tabular}

According to table 8, independent sample t-test table reveals that there is no significant difference in the opinion of male and female regarding leadership practice delegating score $(\mathrm{t}=.35$, sig=.93, Mean male $=35.47$, Mean female $=35.60)$. Female principal rated leadership practice delegating better than male principal.

\section{Findings}

These were the major findings of the study on the analyses basis: Head teachers were the sample groups.

\section{Direction}

i. $\quad$ The independent sample t-test table (Table 4.1.21) reveals that there is significant difference in the opinion of male and female regarding leadership practice.

ii. The independent sample t-test table (Table 4.1.25) reveals that there is significant difference in the opinion of male and female teachers regarding leadership practice.

iii. The independent sample t-test table (Table 4.1.29) reveals that there is significant difference in the opinion of public and private schools principal regarding leadership practice.

iv. The independent sample t-test table (Table 4.1.33) reveals that there is no significant difference in the opinion of public and private schools teachers regarding leadership practice.

\section{Coaching}

i. $\quad$ The independent sample t-test table (Table 4.1.22) reveals that there is no significant difference in the opinion of male and female regarding leadership practice.

ii. The independent sample t-test table (Table 4.1.26) reveals that there is significant difference in the opinion of male and female regarding leadership practice.

iii. The independent sample t-test table (Table 4.1.30) reveals that there is significant difference in the opinion of public and private schools principal regarding leadership practice.

iv. The independent sample t-test table (Table 4.1.34) reveals that there is no significant difference in the opinion of public and private schools teachers regarding leadership practice.

\section{Supporting}

i. $\quad$ The independent sample t-test table (Table 4.1.23) reveals that there is significant difference in the opinion of male and female regarding leadership practice.

ii. The independent sample t-test table (Table 4.1.27) reveals that there is no significant difference in the opinion of male and female regarding leadership practice. 
Vol. II, Issue 3, Oct - December 2021

ISSN No: (ONLINE): 2710-043

www.irjei.com
International Research Journal of Education and Innovation

ISSN No: ISSN (PRINT): 2710-0448

DOI: https://doi.org/10.53575/irjei.v2.03(21)3.35-43

Head Teacher AS A Leader: An Analysis of Head Teachers Practices Based ...

iii. The independent sample t-test table (Table 4.1.31) reveals that there is significant difference in the opinion of public and private schools principal regarding leadership practice.

iv. The independent sample t-test table (Table 4.1.35) reveals that there is significant difference in the opinion of public and private schools teachers regarding leadership practice.

\section{Delegation}

i. $\quad$ The independent sample t-test table (Table 4.1.24) reveals that there is no significant difference in the opinion of male and female regarding leadership practice.

ii. The independent sample t-test table (Table 4.1.28) reveals that there is significant difference in the opinion of male and female regarding leadership practice.

iii. The independent sample t-test table (Table 4.1.32) reveals that there is significant difference in the opinion of public and private schools principal regarding leadership practice.

iv. The independent sample t-test table (Table 4.1.36) reveals that there is significant difference in the opinion of public and private schools' teachers regarding leadership practice.

\section{Conclusion}

On the basis of analysis and findings conclusion were drawn as following:

1 It is concluded that the leadership practices of male Head teachers is better than as compare to female Head teachers regarding direction and coaching while in supporting and delegation female Head teachers practices are better as compare to male Head teachers practices.

2 It was concluded that the leadership practices of private Head teachers are better as compare to public Head teachers regarding direction, coaching and supporting while in delegation, public Head teachers' practices are better than private Head teachers' practices

\section{Recommendation}

1. Public Head teacher should follow the practices of private school Head teacher

2. Government should provide a plate form in which both public and Private Head teacher share their practices

3. Government should upgrade their teacher and Head teacher regarding coaching according to modern era.

4. Department of education should organize a proper ongoing training for their teacher and Head teacher regarding directing, coaching, supporting and delegation.

5. The management of private schools should organize a proper ongoing training for their teacher and Head teacher regarding directing, coaching, supporting and delegation.

6. The public Head teacher should show positive and cooperative behavior with their teachers

7. There should be need to develop a democrative environment in public schools.

\section{References}

1. Annual data of all secondary schools (2016). District Education Officer Kotli, AJ\&K 
Vol. II, Issue 3, Oct - December 2021

ISSN No: (ONLINE): 2710-043

www.irjei.com
International Research Journal of Education and Innovation

ISSN No: ISSN (PRINT): 2710-0448

DOI: https://doi.org/10.53575/irjei.v2.03(21)3.35-43

Head Teacher AS A Leader: An Analysis of Head Teachers Practices Based ...

2. Annual data of all secondary schools (2016). District Education Officer Sudhnuti, AJ\&K

3. Annual data of all secondary schools (2016). District Education Officer Rawalakot, AJ\&K

4. Avolio, B. J. Walumbwa, F. O., \& Weber, T. J. (2009). Leadership: Current Theories,

5. Awan, A.G. (2014) "Brazil's Innovative Anti-Poverty and Inequality Model," American Journal of Trade and Policy 1 (3).7-12.

6. Bell, R. M. (2013). Charismatic Leadership Case Study with Ronald Reagan as Exemplar. Emerging Leadership Journeys, 6(1), 66-74.

7. Charry, K. (2012). Leadership Theories - 8 Major Leadership Theories. Retrieved March 2014 fromhttp://psychology.about.com/od/leadership/p/leadtheories.htm

8. Chaudhry, A. Q., \& Javed, H. (2012). Impact of Transactional and Laissez Faire Leadership Style on Motivation. International Journal of Business and Social Science, 3(7), 258-264.

9. Goodnight, R. (2011). Laissez-Faire Leadership. Encyclopedia of Leadership. London, UK: Sage Publications.

10. Luneburge, B. A. (2007). Educational administration concept and practice. Belmont. C.A United states: Cenage learning.inc.

11. Ryan, J. (2002): Applying situational leadership in Australia, Journal of Management Development., 21(4), 242-262.

12. Kets de Vries, M. F. R. (2006). The leader on the couch: A clinical approach to changing people and organizations. San Francisco, CA: Jossey-Bass

13. Kozes, J, Posner. B. (2002). The leadership challenges (3rd Ed.). San Francisco Jersey Bass.

14. Lamb, R. (2013). How can Managers Use Participative Leadership Effectively? Retrieved from http://www.task.fm/participative leadership.

15. Gay, L.R. (2015). Educational Research. Islamabad: Pak Edition.

16. Lussie, R. N. Achua. C. F. (2004). Leadership: theory, application, skill development (2 ${ }^{\text {nd }}$ Ed.). America Library of Congress: south western publishing co.

17. Mulder,P.(2012). Situational Leadership Model (SLM). Retrieved from: https://www.toolshero.com/leadership/situational-leadership-Hersey-Blanchard

18. Northouse, G. (2007). Leadership theory and practice. (3rd ed.) Thousand Oak, London, New Delhe, Sage Publications, Inc.

19. Wamy, T. S. \& Swamy D. R. (2014) Leadership Styles; Department of Industrial Engineering and Management, JSS Academy of Technical Education, Bangalore, INDIA Vol. 7(2).

20. Neto, A. S. ( 2014). A study of the aplicability ofth insituational leadership acording to Hersey Blanchard. Tactful Management Research Journal .

21. North house, P. G. (2004). Leadership theory and practice (3 ${ }^{r d}$ Ed.). Sage Publication.

22. Ololube, N. P. (2013). Educational Management, Planning and Supervision: Model for Effective Implementation. Owerri: SpringField Publishers.

23. Santrock, J. W. (2007). A Topical Approach to Life-Span Development. New York, NY: McGraw-Hill.

24. Schaefer, R. T. (2005). Sociology. (9th Ed). New York, NY: McGraw-Hill.

25. Shami, P. A. \& Hussain, S. K. (2007).Education in Pakistan. Islamabad: Academy of Education of Planning and Management.

26. Wetherell, M. Karen, "Principal Leadership Style and Teacher Job Satisfaction" (2002). Seton Hall University Dissertations and Theses (ETDS).

Retrieved from http://scholarship.shu.edu/dissertations/1400.

27. Yukl, G.A. (2002). Leadership in organization ( $5^{\text {th }} E d$ ).London: New Jersey Prentice Hall.

28. Zichy, S. (2001). Women and the leadership: The breakthrough system for achieving power and influence. Retrieved from: http://site.ebrary.com

29. Collins English Dictionary - Complete and Unabridged, 12th Edition 2014 HarperCollins

30. Publishers, 201. 